\title{
TRAMVAJUS IR (ARBA) METROPOLITENAS VILNIAUS URBANISTINĖJE STRUKTŪROJE. PASIŪLYMAI IR ARGUMENTAI
}

\author{
Pranciškus Juškevičius ${ }^{1}$ Vidualdas Valeika ${ }^{2}$ Kristina Jauneikaité ${ }^{3}$ \\ ${ }^{1}$ Urbanistikos katedra, Architektūros fakultetas, Vilniaus Gedimino technikos universitetas, \\ Pylimo g.26/Trakug. 1, LT-01332 Vilnius, Lietuva. El. paštas sj@amstudio.lt \\ ${ }^{2}$ St „Vilniaus planas“, Konstitucijos pr. 3, LT-09601 Vilnius, Lietuva. El.paštas vidualdas.valeika@vilnius.lt \\ ${ }^{3}$ Miestų statybos katedra, Aplinkos inžinerijos fakultetas, Vilniaus Gedimino technikos universitetas, \\ Sauletekio al. 11, LT-10223 Vilnius, Lietuva.El.paštas kris@ap.vgtu.lt
}

Itteikta 20080626

Santrauka. Vilniaus susisiekimo problemas sukūrè ir toliau kurs gyventojų mobilumas ir pasirenkamos susisiekimo priemonės, taip pat ir gyvenimo būdas urbanistinès struktūros, gatvių tinklo ir kitokio tipo aplinkoje. Tokios visumos reguliavimas (valdymas) ir yra problemų sprendimo raktas. Dabartinėse diskusijose apie tokią visumą arba apie tramvajaus, metropoliteno funkcionavimo aplinką neužsimenama. Problemos sprendimui priskirtinos pastangos rasti tinkamas viešojo ir asmeninio susisiekimo sistemų išvystymo proporcijas. Straipsnyje nagrinėjama socialinė ir politinė susisiekimo sistemos aplinka, susisiekimo kokybė, faktinis transporto priemonių srautas ir vežimų galia, mobilumo valdymas, urbanistinės struktūros svarba apskritai ir konkrečiai Vilniaus atveju. Pateikiami pasiūlymai ir argumentai tramvajaus diegimo klausimu.

Reikšminiai žodžiai: miesto susisekimo sistema, tramvajus, metropolitenas, mobilumas, urbanistinè struktūra.

\section{Ivadas}

Pirmojoje straipsnio dalyje Tramvajus ir (arba) metropolitenas Vilniaus urbanistineje struktūroje. Vystymo prielaidos buvo nagrinejama šalyje ir pasaulyje susiklosčiusi socialinè, politinè bei finansinè aplinka, jos reikšmè kokybiškos sistemos vystymui. Analizè parodè, kad politinè, sprendimus priimanti aplinka yra nepalanki sisteminiams Vilniaus transporto problemų sprendimams. Tramvajui paliekamas antraeilis vaidmuo, atspindintis susisiekimo sistemos vystymo politinio neapibrěžtumo ir gyventojų informuotumo lygị. Remiantis naudos ir išlaidų santykio požiūriu metropoliteno, kaip tramvajaus alternatyvos, privalumų tikimybe artima nuliui. Šio straipsnio tikslas tiesiogiai nèra susijęs su tramvajaus (Tw) ir metropoliteno $(M)$ statybos darbų rinkos, ịrangos montavimo, vagonų tiekimo ir kt. konkurencijos, lobizmo peripetijomis. Tačiau aišku, kad tokių veiksnių įtaka bus neišvengiama.

$T w$ ir $M$ kūrimo kontekstas yra nepaprastai platus. Tai ne vien susisiekimo paslaugų rinkos vystymas, bet ir socialinès, ekonominès bei kitos Tw ir $M$ sistemu vystymo arba nevystymo pasekmès gyventojų mobilu- mui, struktūrinei ir apskritai miesto raidai. Ir atvirkščiai - išankstinès sąlygos yra labai svarbios prielaidos integruotai bèginio transporto ir miesto sistemų raidai. Tramvajus ir regioninis, kartu ir miesto geležinkelis turi didelę vystymo perspektyvą integruotoje Vilniaus metropolio susisiekimo sistemoje, o metropolitenas artimiausiais dešimtmečiais objektyviai netaps alternatyva tramvajui. Nustatyti to priežastis ir suformuluoti pasiūlymus, kaip būtų galima pašalinti neigiamas pasekmes, ir yra šio straipsnio tikslas.

\section{Vežimų galia ir faktinis transporto priemonių srautas}

Transporto linijų keleivių vežimo galia priklauso nuo trijų esminių veiksnių - važiavimo dažnių, transporto priemonès talpos (jos panaudojimo) ir važiavimo sąlygų (greičių). Būdingi tokie galios dydžiai:

- lengvojo automobilio (šviesoforais reguliuojamo eismo gatve, užpildymas 1,3 kel./aut.) 1 eismo juosta $1200 \mathrm{kel} . / \mathrm{h}$,

- autobusų linija 3 000-6 000 kel./h, 
- tramvajaus linija $8000-15000 \mathrm{kel} . / \mathrm{h}$,

- metropoliteno linija $20000-40000 \mathrm{kel} . / \mathrm{h}$.

Aukšto automobilizacijos lygio sąlygomis šie $T w$ ir $M$ linijų vežimų galios dydžiai greičiau yra galimybių iliustracija ir tikslas, kurị ịmanoma pasiekti tik labai dideliuose miestuose. Remiantis šiame straipsnyje naudotų šaltinių duomenimis, faktiniai ir planuojamieji vežamų keleivių skaičiai labai svyruoja: Tw liniju - 30-180 tūkst. kel./parą, $M$ liniju - 50-250 tūkst. kel./parą (apytikriai kamšos valandą būtų 10 kartų mažesnis keleivių skaičius) Tw ir Mlinijų tiesimo išlaidos iš dalies yra pastovesnis dydis negu galintis susiformuoti keleivių srautas. Todèl santykinès išlaidos yra geresnis efektyvumo rodiklis, ypač esant ribotoms finansinèms galimybèms subsidijuoti tokias sistemas. Remiantis (Albanese J. et al. 2006) straipsnio duomenimis, linijų tiesimo išlaidų santykinis dydis būna nuo 24 iki $162 \mathrm{Lt}$ /keleiviui per metus. Akivaizdu, kad keleivių srauto dydis yra esminis efektyvumo veiksnys ne vien $T w$ ir $M$ apibūdinti. Informatyvus $T w$ linijos tiesimo santykinès kainos palyginimas su kitų veikiančių susiekimo būdų kainomis (2003 m. kainos, Kanada, Kvebekas (Accés transports viables 2006):

- tramvajus $59 \mathrm{Lt} / 1$ kel. per metus,

- metropolitenas $101 \mathrm{Lt} / 1$ kel. per metus,

- priemiestinis geležinkelis $171 \mathrm{Lt} / 1$ kel. per metus,

- automagistralè (lengvieji automobiliai) $735 \mathrm{Lt} / 1 \mathrm{kel}$. per metus.

Remiantis natūrinių tyrimų duomenimis geriausias laikotarpis Vilniaus tramvajui buvo apie 1980 metus:

\begin{tabular}{lccccc}
\hline Metai & 1966 & 1971 & 1980 & 1998 & 2002 \\
\hline $\begin{array}{l}\text { Pervežta tūkst. kel. } \\
\text { per parą }\end{array}$ & 543,0 & 687,8 & 1030,4 & 831,7 & 710,0 \\
\hline
\end{tabular}

Taigi viešojo transporto patrauklumas ir Tw potencialas mažeja. Tiesa, remiantis Statistikos departamento ir SI „Susisiekimo paslaugos“ duomenimis $\left(^{*}\right)$, galima padaryti kitokias išvadas:

\begin{tabular}{lcccc}
\hline Metai & 1980 & 2000 & 2003 & 2006 \\
\hline $\begin{array}{l}\text { Pervežta tūkst. } \\
\text { kel. per parą * }\end{array}$ & 283,1 & 201,7 & 263,1 & 313,7 \\
\hline $\begin{array}{l}\text { Persèdimu } \\
\text { koeficientas (pk) }\end{array}$ & 1,2 & 1,4 & 1,5 & 1,6 \\
\hline $\begin{array}{l}\text { Tūkst. kelioniụ } \\
\text { per parą (iverti- } \\
\text { nus pk) }\end{array}$ & 235 & 150 & 179 & 195 \\
\hline
\end{tabular}

Tai būtų neteisinga išvada, nes „pervežta keleivių“ ir „kelionès“ yra skirtingos sąvokos. Statistiškai skirtumus lemia ne vien persèdimai. Tai atskira tema, čia verta pabrèžti, kad ịsisenèjusią problemą galètų išspręsti susisiekimo stebèsenos sistema. Be jos yra didelè duomenų sisteminių klaidų ir nepagrịstų interpretacijų tikimybè.

Vilniaus miesto zonose viešojo transporto keleivių srautų mažèjimas yra diferencijuotas:

\begin{tabular}{lllll}
\hline Metai & & 1980 & 1998 & 2002 \\
\hline Centro zona & $0-3 \mathrm{~km}$ & 170 & 95 & 79 \\
\hline $\begin{array}{l}\text { Vidurinè } \\
\text { zona }\end{array}$ & $3-6 \mathrm{~km}$ & 145 & 52 & 52 \\
\hline $\begin{array}{l}\text { Periferine } \\
\text { zona 6-9 km }\end{array}$ & 4,4 & 4,5 & 4,7 & \\
\hline
\end{tabular}

Šie duomenys iliustruoja metropolizacijos pasekmes: gyventojų skaičiaus mieste mažejimą, jų svorio centro slinktị i periferiją ir periferinès bei subperiferinės zonų gyventojų švytuoklinės migracijos lengvaisiais automobiliais egzistavimą.

Maksimali linijinè keleivių koncentracija viešojo transporto linijose $1980 \mathrm{~m}$. sudarè, o $2002 \mathrm{~m}$. sumažèjo iki 5,5 tūkst. kel./h abiem kryptimis (1 pav.). Be to, ryškejja, kad linijinès koncentracijos trumpejja ir nesusiformuoja palankios trasos.

Pastaraisiais metais neigiami gatvių kamšos reiškiniai pakeitè susisiekimo būdų privalumus: $1998 \mathrm{~m}$. rytinès kamšos valandomis vežimai autobusais ir maršrutiniais taksi sudare 3,7 dabar - apie 9,3 proc.

Tai palanki, tačiau ne vyraujanti tendencija. Išlieka VT nuosmukio tendencijos, o kartu egzistuoja net pirmosios $T w$ linijos apkrovimo rizika.

\section{Mobilumo valdymas}

Tramvajaus apkrovimo riziką gali sumažinti mobilumo valdymas.

Mobilumas yra pagrindinè urbanistikos paradigma (Juškevičius 2004). Jị apibūdina gyventojų kelionių dažnis, trukmé, ilgis, išlaidos ir kelionių sklaida konkrečioje urbanistinejje erdvèje, socialinèje, ekonominejje ir kitoje aplinkoje. Mobilumas - tai ir gyvenimo būdas.

Žmogus ji pasirenka laisvai arba aplinkybių yra priverstas pasirinkti vieną ar kitą susisiekimo būdą, trumpas ar ilgas keliones ir pan. Ribotos komunikacinio mobilumo pasirinkimo galimybės, žema paslaugu kokybė ir didelè jų kaina skatina lokalụj mobilumą, t. y. skatina pasirinkti kitą gyvenamąją vietą toje pačioje 


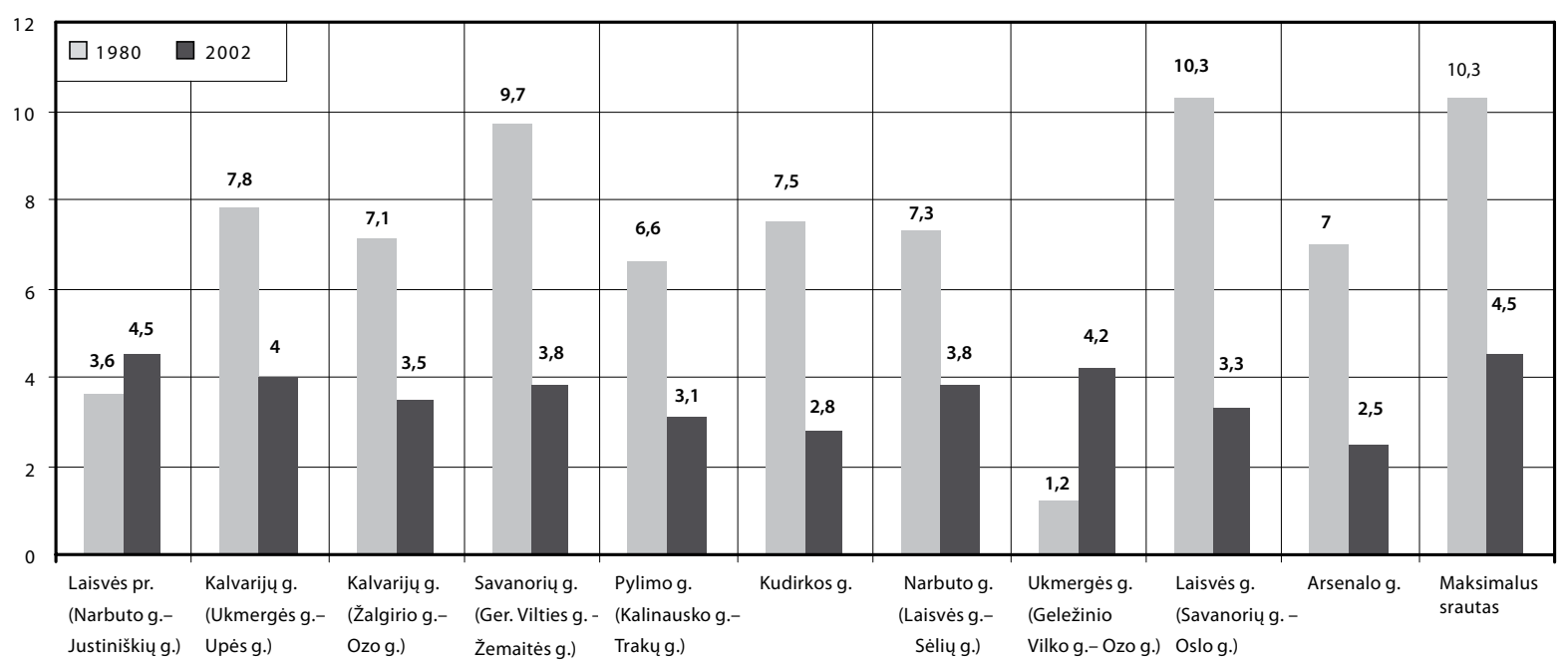

1 pav. Vilniaus viešojo transporto vienos krypties keleivių maksimalių srautų dinamika, tūkst. kel./h

Fig. 1. Dynamic of maximum one-way passenger flows in Vilnius public transport system (thous. pass./h)

ar kitoje urbanistinejje struktūroje. Trečiasis pasirinkimo tipas - virtualusis mobilumas (mobilusis telefonas, internetas ir pan.), t. y. nepriklausoma nuo susisiekimo sistemos komunikavimo priemone. Tai supaprastinta mobilumo schema, tačiau gerai rodanti tiesioginị ryši su šio straipsnio tema.

Mobilumo valdymas - tai viešojo transporto rinkos formavimas, lemiantis atitinkamas pasekmes lengvųjų automobilių naudojimo sferoje, urbanistinio planavimo ir miesto valdymo pokyčius.

Yra du mobilumo valdymo lygmenys: urbanistinio planavimo lygmuo ir žemesnis - konkrečių priemonių bei ịrankių rinkinys.

Senosiose ES šalyse judrumo valdymo samprata egzistuoja jau kelis dešimtmečius. Lietuvoje tai nèra naujiena, išskyrus oficialų urbanistinio planavimo lygmenị. Čia mobilumo valdymas neegzistuoja jokia forma. Kiekvienas Jungtinès Karalystès administracinis vienetas privalo turèti savo transporto planą: regionas - transporto strategiją, savivaldybè - vietini transporto planą, dar žemesniame lygmenyje (maždaug teritorijos užstatymo projektas) - judrumo valdymo schemą, parengtą laikantis pagrindinio nacionaliniuose dokumentuose nurodyto principo: judrumo valdymas turi būti pagrindinè priemonè išvengti transporto problemų, ypač lengvųjų automobilių srauto didejjimo urbanizuojant naujas teritorijas. Vokietijoje rengiami strateginiai transporto plètros planai, arba mobilumo planai (masterplan mobilitat), apimantys visas transporto rūšis nagrinëjamame rajone 5-15 metų perspektyvai. Detalesni 5 metu planai (nahverkehrsplan) yra skirti konkrečiai transporto rūšiai ( $T w, M$ ir kt.) arba konkrečios teritorijos gyventojų ir svečių mobilumui valdyti.
Europos Komisijos finansuojamų projektų, susijusių su mobilumo valdymu, dalyviai, atstovaujami Austrijos mobilumo tyrimų biuro Grace, $2007 \mathrm{~m}$. pagrindines mobilumo valdymo priemones klasifikavo taip (Definition and Categorisation of Mobility Management Measures 2007):

- informacinès ir agitacinès;

- organizacinès: Car Pool ir panašios sistemos, dviračių nuoma, VT iškvietimas telefonu ir kt.;

- mokymo; jos suprantamos kaip judrumo valdymo žinių integravimas į mokinių, studentų studijas, paslaugų profesijų mokymą;

- telekomunikacijos (virtualusis mobilumas), pakeičiančios fizines keliones ị darbo, paslaugu ịstaigas, imones ir kt., pirkimus ir pramogas;

- darbo laiko organizavimas: dirbama mažiau dienų per savaitę, perskirstoma darbo pradžia;

- palaikančiosios: mokesčiai ir rinkliavos, didinantys lengvojo automobilio naudojimo kainą; automobilių saugyklų ribojimai; kombinuoti renginių ir kelionès VT bilietai ir pan.

Charakteringas tokių priemonių taikymo pavyzdys - Lisabonos metropolitenas. 2004 m., prieš tiesiant naująją $M$ liniją, buvo atlikta ne tik potencialių keleivių, linijos trasos išsami analize, bet ir propaguotas metropolitenas: buvo apklausti trasos prieigose esančių darboviečiu atstovai, o darbuotojams siūlomos lengvatinès sąlygos naudotis $M$; gyventojams surengtos reklaminès ir kitokios kampanijos, kurios dar kartą patikrino naujos linijos poreikị, skatino persessti išlengvojo automobilio $i \mathrm{i} M$ (Dirvos ruošimas naujajam Almados tramvajui 2004).

Atrodytų, kad tokiame kontekste galima būtų teigti, kad Vilniuje mobilumas taip pat valdomas. Kiekvienas 
naujas gyvenamasis, pramogų, paslaugų ir bet koks kitas objektas, nauja ar rekonstruojama gatvè, valstybès reikšmès svečio vizitas, rinkliavų ir mokesčių dydžių kaita, net bet kuris didesnis eismo įvykis keičia eismo sąlygas ir mobilumą. Tačiau nè vienas vienoks ar kitoks sąlygų pokytis mobilumui nèra identifikuojamas, t. y. mobilumo valdymas, kaip sąmoningi ir orientuoti ị tikslą veiksmai, Vilniaus miestui nebūdingi. Siemens arenos, Akropolio komplekso, nacionalinio 25 tūkst. žiūrovų stadiono, vandens parko dislokacija seniai žinomos pirmosios tramvajaus trasos ir kitų jau esamų VT linijų atžvilgiu yra praleisti esminès svarbos mobilumo valdymo atvejai.

\section{Tramvaju ir metropolitenų sistemų renesansas}

Postūmį tramvajų ir metropolitenų sistemų renesansui suteikè pirmoji 1973-1974 metų energetinè krizè, masinè automobilizacija ir jos padarinys - aukšta išorinè kaina. Tai priežastys, dèl kurių pasikeitė miestų susisiekimo politika, bėginiam transportui suteikusi finansini pagrindą. Prancūzija pirmoji pradèjo diegti tramvajų sistemą ir jos miestai daugiausia yra padarę nuo 1985 m., kai buvo atidaryta Nanto tramvajaus linija, kuri tapo tramvajų renesanso pradžia. Iki $2003 \mathrm{~m}$. naujos tramvajų linijos pradejjo veikti 8 miestuose (Burmeister 2005). 2007 m. Paryžiaus regionui buvo skirta $4,8 \mathrm{mln}$. Lt užbaigti 4 ir pradèti 6 nauju liniju tiesimo darbus (Tramway en Ile-de-France-où en est-on? 2007). Planuojama, kad iki $2010 \mathrm{~m}$. kituose 24 Prancūzijos miestuose bus nutiestos naujos Tw linijos (Transports urbains. Tramways en France 2007).

Renesansas apėmè apskritai visas bėginio transporto rūšis daugybejje Europos miestų. Šis procesas aktyviausias Atenuose, Helsinkyje, Londone ir kituose JK miestuose, Maskvoje, Vienoje, Budapešte, Bukarešte, Amsterdame, Roterdame, Hagoje, Utrechte, Prahoje, Ciuriche (Other UK systems 2003; Mellas 2007; Järviluoma 2007; Rat, Pourbaix 2007; Vasiljev 2007; Hoogehuijs 2005; Wansbeek 2007). Net Los Andželo regione, kuriame nuo $1961 \mathrm{~m}$. neliko miestą ir priemiestị aptarnaujančių geležinkelio linijų (1945 m. jų buvo $1873 \mathrm{~km}$ ) ir kuris iki šiol garsejja tuo, kad transporto infrastruktūra užima 70 proc. miesto teritorijos, susisiekimo įmonè MTA 1990-2003 m. ịrengè ir eksploatuoja dvi lengvojo geležinkelio ir vieną metropoliteno liniją (bendras jų ilgis $117 \mathrm{~km}$ ), tiesiama ketvirtoji linija (Wansbcek 2007).

Tramvajaus atgimimas paskatino transporto sistemų integraciją. Vienas iš jos tipų - tramvajaus, geležinkelio, metropolitenų techninių sistemų integra- cija. Nuo 1992 m. Karlsrūhèje tramvajaus sąstatas gali naudotis geležinkelio linijomis (Andrusiewicz; Grulikowski 2001). 2006 m. pradètas igyvendinti ES dotuojamas projektas, skirtas tramvajų, greitujų tramvajų ir metropolitenų bėgių infrastruktūrai suderinti (Track - Harmoniesierung stätischer Schienen - infrastruktur 2007). Kito tipo projektas baigiamas igyvendinti Nyderlanduose - Roterdamo priemiestinis geležinkelis integruojamas su metropolitenu (Badcock 2006).

Tramvajų atgimimas tampa miestų atnaujinimo būdu ir šiandien suprantamas kaip modernumo bei ekonominès sèkmès sinonimas. Straipsnyje Bègiu transportas - Londono ateitis tvirtinama: jeigu viešojo transporto tinklo ir pajègumų plètra nebus adekvati planuojamai raidai (per 20 metuc - apie $1 \mathrm{mln}$. darbo vietu padidejimas), kils rizika, kad kapitalas ir investicijos persikels $\mathfrak{i}$ kitus tarptautinius verslo centrus Europoje. Tai reikštų milijardinių mokesčiu praradimą, nedarbą ir augimo perspektyvų netekimą visame Londono regione (Brown 2007).

Miestų konkurencija stipreja. Vilnius taip pat dalyvauja konkurencineje kovoje. Tačiau jo pajegumą ir patrauklumą mažina transporto problemos. Tramvajaus sistema gali tapti veiksniu, skatinančiu sisteminę pažangą - gyvenimo kokybę, investicijas, turizmą ir kt. Sèkmès pavyzdžiai - dažniausiai tramvajaus renesanso miestai.

Tačiau tramvajų renesansas neatmeta nè vienos iš klasikinių viešojo transporto rūšių, jų integracijos organizacinių ir techninių formų. Tarp jų yra autobusų ( $a$ la metro) sistema, pasiūlyta K. Majerio 1972 m. (SSRS), kai kur veikianti, kai kur vis atgyjanti naujos idejos forma. Esama ir naujų transporto rūšių. $2002 \mathrm{~m}$. Šanchajuje pradejo veikti pirmoji pasaulyje komercinè MAGLEV (magnetinès pagalvès principas) linija. Ji jungia periferinę $M$ stotị su $30 \mathrm{~km}$ nuo jos nutolusiu oro uostu, susisiekimo trukmè - $7 \mathrm{~min}$, greitis - iki $430 \mathrm{~km} / \mathrm{h}$. Reikia tikètis, kad panašios sistemos nebus dar viena nauja alternatyva Vilniaus tramvajui.

\section{Urbanistinès struktūros}

Ekonominiu ir gyvenamosios aplinkos kokybès požiūriu $T w$ ir $M$ privalumus lemia jų linijų santykinis apkrovimas, apkrovimo pastovumas erdvejje ir laike (per parą ir per metus), trasos ilgis. Šie trys dydžiai makropožiūriu tiesiogiai koreliuoja su miesto dydžiu. Vilnius yra peržengęs pradinį maždaug 300 tūkst. gyv. slenkstị. Tačiau toliau svarbiausiais veiksniais tampa morfologinè ir funkcinè miesto struktūra, formuojanti mobilumo - ryšių, kaip vektorių, sklaidą miesto ir jo 
regiono erdveje ir laike. $T w$ ir $M$ linijoms palankus tik linijinès koncentruotos sklaidos tipas.

- Iki 10-15 gyv./ha tankio teritorijos traktuojamos kaip erdvès, palankios tik lengvajam automobiliui.

- Iki 25 gyv. ir darbo vietų/ha tankio teritorijose mobilumo viešuoju transportu tikimybè yra apie 10 proc.

- Apie 30 gyv.ha tankis gali suformuoti minimalią rinką viešajam transportui, apie 70 gyv./ha tankis teikia geras prielaidas viešajam transportui gyvuoti;

- >80 gyv. ir darbo vietų/ha tankis mobilumo viešuoju transportu tikimybę gali padidinti iki 60 proc.

Vilnius neturi linijinès struktūros požymių, o vidutinis gyventojų tankis yra artimas 30 gyv./ha. Gyventojų tankio mažejjimo tendencija užprogramuota ilgam, nes Vilniaus miesto ekspansija ị priemiestị ir metropolio formavimasis dar tik prasidejo. Ją pradeda papildyti naujos ar iš miesto perkeltos darbo vietos. Todèl pasikeite ir keisis gyventojų tankio ir susisiekimo būdụ reikšmès proporcijos:

\begin{tabular}{lccc}
\hline Metai & 1960 & 2007 & 2025* \\
\hline $\begin{array}{l}\text { Gyventojų tankis, } \\
\text { gyv./ha }\end{array}$ & 72 & 30 & $?$ \\
$\begin{array}{l}\text { VT santykinè dalis (kel. } \\
\text { km), proc. }\end{array}$ & 90 & 30 & 20 \\
\hline $\begin{array}{l}\text { La santykinè dalis (kel. } \\
\text { km ), proc. }\end{array}$ & 10 & 70 & 80 \\
\hline
\end{tabular}

* Dèl daugybès vidiniu ir išoriniu veiksniu, taip pat ir Vilniaus metropolio vystymosi spartos iki $2025 \mathrm{~m}$. neapibrezžtumo gyventoju tankio vidurkis nebus charakteringas dydis. Jeigu išliks dabartinès tendencijos, VT dalis sumažetu iki minimalaus socialiniu paslaugu lygio, o La dalis- iki maksimalaus prisotinimo.

Taigi makropožiūriu Tw ar $M$ linijų tiesimas yra ir gali išlikti problema, jeigu automobilizacija bus nevaržoma, o metropolizacijos procesas liks nereguliuojamas. $T w$ gali išlaikyti greito susisiekimo patrauklumą tik tuo atveju, kai papildomos laiko išlaidos kiekvienam keleiviui yra $<5 \mathrm{~min}$. Tačiau tokiu atveju linija aptarnautu $500 \mathrm{~m}$ pločio koridorių. Iš tokio $10 \mathrm{~km}$ ilgio koridoriaus, esant tam tikram gyv./ha Vilniuje tankiui ir mobilumo tramvajumi 0,3 tikimybei (t. y. 1,5 didesnei negu dabartinis mobilumas VT) ir tarpstočių ilgiui $500 \mathrm{~m}$, galima tikètis tokių vidutinių maksimalių apkrovų:

\begin{tabular}{lll}
\hline Tankis, gyv./ha & $\begin{array}{l}\text { Koridoriaus } \\
\text { plotis, } \mathbf{m}\end{array}$ & Apkrova, kel./h \\
\hline 30 & 500 & 1500 \\
\hline 30 & 1000 & 6000 \\
\hline 60 & 1000 & 12000 \\
\hline 60 & pasiekiamumo & 15000 \\
\hline \multicolumn{3}{l}{ spindulys 700 m } \\
\hline
\end{tabular}

Paprastai metropoliteno tarpstočiai yra ilgesni, papildomos laiko išlaidos (nusileisti ị stotị ir pan.) didesnès, todèl apkrovos formavimu ir susisiekimo „nuo durų iki durų“ greičiu metropolitenas Vilniaus struktūroje negalètų konkuruoti su $T w$. Be to, integracijos su antžeminiais susisiekimo būdais metropoliteno galimybès yra blogesnès.

Jeigu teritorijos būtų funkciškai integruotos, pakankamas argumentas galètų būti vien gyventojų ir darbo vietų tankis. Tokia yra tik centrinė Vilniaus dalis. Daugumai rajonų būdingi specializacijos bruožai gyvenamieji, pramonès rajonai, specializuoti centrai (medicinos, mokslo, studijų), sodų bendrijos, didieji prekybos ir pramogų kompleksai. Todèl pasidaro svar$\mathrm{bu}$, kokius rajonus jungs viena ar kita Tw linija. Nuo to priklausys apkrovimo pastovumas per parą.

Tramvajaus apkrovos gali būti didesnès, tačiau tam reikia specialių pastangų. Vienas iš pavyzdžių - ištrauka iš 30 metų senumo strategijos, taikytos viešojo transporto ir lengvųjų automobilių naudojimui reguliuoti (Maxman, Stuart 1978):

\begin{tabular}{|c|c|c|c|}
\hline Strategija & \multicolumn{3}{|c|}{$\begin{array}{l}\text { Efektas ( }+/ \text { - kelionių i miesto centrą } \\
\text { proc.) }\end{array}$} \\
\hline $\begin{array}{l}\text { La privalumų } \\
\text { mažinimas }\end{array}$ & La & VT & $\begin{array}{l}\text { La (pavèžèjimų } \\
\text { susitarimo } \\
\text { sistema) }\end{array}$ \\
\hline
\end{tabular}

a) ilginama kelionès

pèsčiomis dalis

\begin{tabular}{lccc}
\hline 5 min & -7 & +23 & -6 \\
\hline 10 min & -14 & +47 & -13 \\
\hline 15 min & -22 & +75 & -12 \\
\hline $\begin{array}{l}\text { b) pėsčiujų zonu } \\
\text { irengimas }\end{array}$ & -3 & +12 & -4 \\
\hline $\begin{array}{l}\text { c) mažinama stovejji- } \\
\text { mo trukme }\end{array}$ & -13 & +28 & +5 \\
\hline $\begin{array}{l}\text { d) autobusu liniju } \\
\text { irengimas }\end{array}$ & -3 & +9 & -1 \\
\hline
\end{tabular}

Šiuolaikinès politikos elementas - automobilių stovejimo vietų mažinimas. Remiantis (Rat, Pourbaix 2007) straipsnyje paskelbtais duomenimis, 5 stovejjimo vietos 10 darbo vietų lemia tik 10 proc. VT indeli. Penkis kartus sumažinus stovejjimo vietų skaičių, VT populiarumas padideja 5 kartus. Jungtinès Karalystès, Prancūzijos miestuose automobilių vietų skaičius prie naujų pastatų normuojamas priklausomai nuo atstumo iki Tw ar $M$ stočių; Vienos, Nanto, Kopenhagos, Ciuricho miestų centrų automobilių vietų skaičius negali būti didinimas (Rat, Pourbaix 2007). 


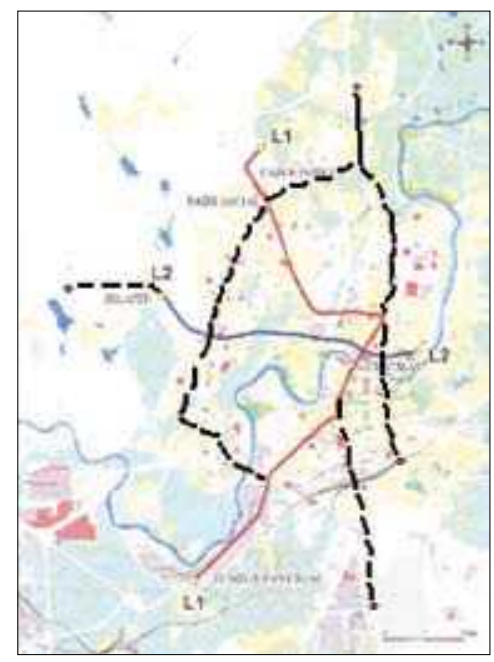

2 pav. 1980-1983 m. Vilniaus generalinio plano greitojo tramvajaus pirmosios dvi (raudona ir mèlyna) linijos ir 1996 m. bei 1998 m. bendrujų planų tokių pat pirmujų liniju trasu papildiniai

Fig. 2. First two (red and blue) fast-tram lines from 19801983 Vilnius General Plan and complements of such first lines in 1996 and 1998 Master Plans

Kitas pavyzdys - vadinamoji $\mathrm{P}+\mathrm{R}$ sistema, Europoje pradèta taikyti Hamburge 1965 m. Šiai sistemai reikia papildomų lèšų automobilių saugykloms ịrengti, o keleiviams - laiko persèsti iš La ił Tw. Sistema ypač efektyvi, jeigu ją papildo finansiniai svertai: nemokamas VT bilietas, mokamas ịvažiavimas ị centrą, mokamas La stovejjimas.

Visi čia pateikti argumentai rodo, kad Vilniuje skiriant dideles finansines lěšas, jeigu pakaks gebëjimų suformuoti daug didesnio gyventojų ir darbo vietų tankio, funkciškai integruotą miesto koridorių, tramvajus gali būti efektyvus ir stabilus viešojo susisiekimo sistemos elementas. Šiandien panašų vaidmenị atlieka troleibusų sistema.

Svarbus grịžtamasis ryšys: tramvajaus tinklas neišvengiamai bus urbanistinès struktūros transformavimo veiksnys. Tai tiesioginès sąsajos su miesto plètros strategija. Geriausiai šią mintị atspindi 1980-1983 m. dvi svarbiausiosios greitojo $T w$ trasos - dviejų didelių gyvenamųjų masyvų jungtys su miesto centru ir dideliu pramonès rajonu (2 pav.).

Iš 1996 m. ir 1998 m. planuojamų tinklų sèkmingiausia yra šiaurès-pietų trasa, stiprinanti centrinị miesto koridorių ir didinanti miesto centro plètros galimybes. $T w$ žiedas yra formalus. Tw ir $M$ tinklų formavimo teorija ir praktika paprastai pabrežia, kad pirmosios dvi linijos plane turetų sudaryti kryžių, trečioji linija - atkirsti

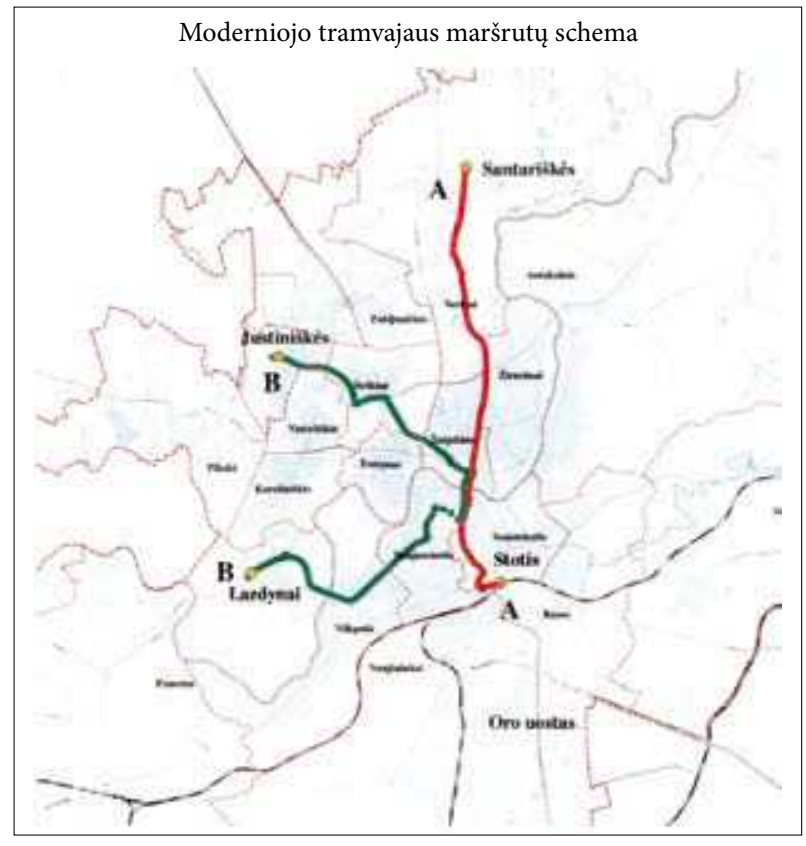

3 pav. Moderniojo tramvajaus linijos. 2002 m. Sl Vilniaus planas, SYSTRA

Fig. 3. Modern tram lines, 2002. ME "Vilniaus planas", SYSTRA

trikampę ar kitokios formos pagrịsto dydžio centrinių funkcijų teritoriją.

2002 m. moderniojo $T w$ linijos sudaro iš dalies racionalesnị trijų spindulių tinklą, tačiau pratęsia miesto plètros koncentraciją tik viename - šiaurés rytų - sektoriuje (3 pav.).

Apskritai toks vieno sektoriaus protegavimas (greičiau nepagrịstas inertiškumas) yra labai nepalankus tiek susisiekimo sistemos, tiek inžinerinių tinklų tiesimo ir funkcionavimo požiūriu; nepanaudojamos teritorijos, tarp kurių ir miesto centro yra geras susisiekimas, ir taip menkinamos racionalios plètros paieškų galimybès. Suderintą visų miesto sektorių plètros galimybių variantą, remiamą $T w$ ir atitinkamo jo tinklo privalumų, rodo 4 pav. (Juškevičius 2002). Dar vienas tinklo idejos privalumas - tolesnès plètros daugiavariantiškumo galimybès, neišsemtos 4 pav. pažymètų vèlesnès hipotetinės plètros trasų.

Vilniaus gyventojų nuomonę apie susisiekimo būdų vystymo aktualumą rodo $2005 \mathrm{~m}$. gyventojų apklausos 41 miesto rajone duomenys. 5 pav. pažymèti rajonai, kurių gyventojai nurodè didesnį negu vidutiniškai miesto mastu vieno ar kelių transporto rūšių vystymo aktualumą. Tokių požymių sklaida nèra atsitiktinè. Periferiniai rajonai sudaro žiedą, kurių gyventojai labiau vertina susisiekimą lengvaisiais automobiliais. Tai patvirtina ir 


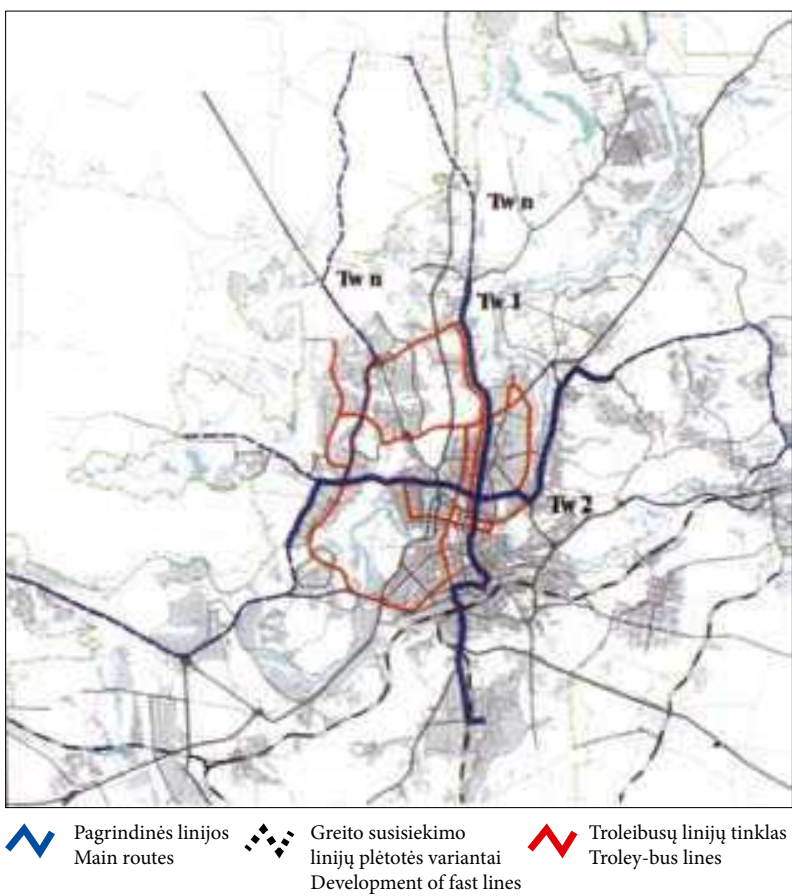

4 pav. Siūlomos tramvajaus liniju trasos ir troleibusų liniju tinklas, 2002 (Juškevičius 2002)

Fig. 4. Proposed tram-line routes and trolley-bus line network, 2002 (Juškevičius 2002)

kitokie duomenys. Rajonai, kurių gyventojai palankiausiai vertina bėginį transportą, formuoja aiškius tramvaju ir geležinkelio linijų koridorius. Tai, kad šie koridoriai bent iš dalies koreliuoja su Tw linijų planuojamomis trasomis, yra svarus argumentas linijų kryžiui. Labiausiai netiketas yra geležinkelio vystymo palaikymas.

Urbanistinè Helsinkio struktūra sparčiai vystosi, ją aptarnauja autobusų (veikia ir greitojo susisiekimo autobusų linija - tokia Vilniuje seniai pamiršta), tramvajų, metropoliteno, priemiestinio geležinkelio ir keltų linijos. Urbanistinès politikos esmè - viešojo transporto vystymo prioritetas, jo sistemos ir užstatymo integracija, vykdoma maždaug nuo 1990 m. Keturiuose pagrindiniuose VT koridoriuose iki pasiekiamumo ribu $2005 \mathrm{~m}$. gyveno 62 proc. gyventoju ir buvo 68 proc. darbo vietu. VT tinklo pajegumą rodo faktas, kad gatviu sraute VT priemonès sudaro net 40 proc. (Järviluoma 2007; Rat, Pourbaix 2007). Vilniuje šis dydis $<10$ proc. Panašia koncentracijos VT koridoriuose politiką vykdo Oslo, Bernas, Viena (Rat, Pourbaix 2007; Stadtentwicklungsplan 1993).

Dèl aktyvios integruotos urbanistinès ir viešojo transporto politikos Stokholmo, Ciuricho, Glazgo, Hanoverio, Vienos, Liverpulio miestų ívaduose VT

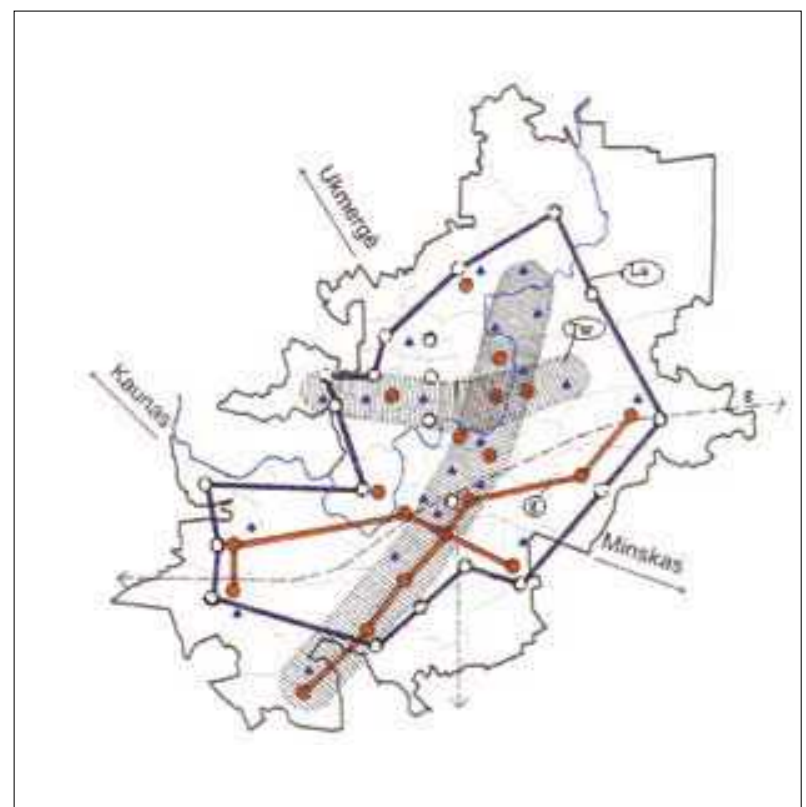

La - lengvojo automobilio didesnio naudojimo rajonų grandine; $T w$, G - tramvajaus, geležinkelio vystymo didesnio aktualumo rajonai; $\mathrm{g}$ - esamos geležinkelio linijos.

5 pav. Vilniaus gyventoju nuomonè dèl lengvojo automobilio naudojimo, tramvajaus ir geležinkelio vystymo reikmės, didesnès negu vidutiniškai mieste, remiantis 2005 m. apklausos duomenimis

Fig. 5. Vilnius residents' vision (according to survey, 2005) of car usage, necessity (bigger than average in city) to develop tram and rail

keleivių dalis (be pėsčiųjų ir dviratininkų) sudaro 5771 proc.

Centrinejje Vilniaus dalyje sukoncentruota 6070 proc. darbo vietų. Kaip to pasekmè - čia didžiausia automobilių ir jų srautų koncentracija. Todèl centro įvaduose VT atvykstančių keleivių dalis yra maža. $2002 \mathrm{~m}$. paskelbtame (Juškevičius 2002) straipsnyje buvo rašoma, kad ypač daug dèmesio turètų būti skiriama Vilniaus šiaurès-pietų koridoriui, nes čia formuojasi funkcinè miesto ašis, kurios gyvybingumą turètų sustiprinti viešojo transporto gatvé, vèliau - tramvajaus linija nuo Riešès iki oro uosto. Ši mintis nepaseno, nepaisant to, kad toks hipertrofiškas Vilniui 25 tūkst. vietu stadionas ir kiti dideli traukos objektai lieka už būsimos pirmosios tramvajaus linijos normalaus pasiekiamumo zonos. Tai elementarių tiesų ignoravimas (kaip ir Baltojo tilto atveju), ko neleidžia sau net ir daug turtingesni miestai.

Tramvajų renesansas per maždaug 20 metų parodè, kad jo efektas matuojamas ne vien ekonominemis, susisiekimo ir sveikesnès aplinkos kategorijomis. Daugelis miestų sugebėjo ị gatves ir aikštes grąžinti socialini gyvenimą, harmonizuoti miesto erdves. 


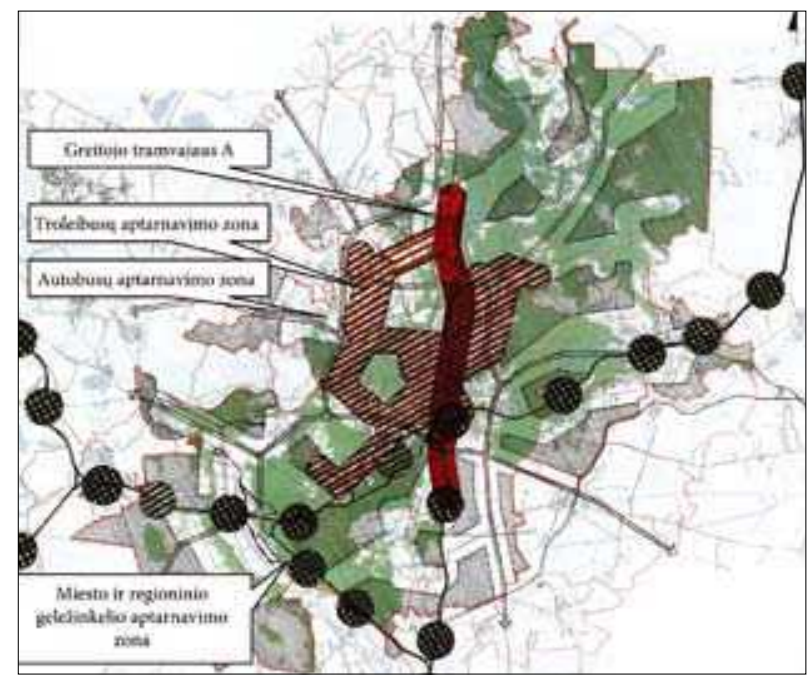

6 pav. Vilniaus metropolio integruotos susisiekimo sistemos siūlomas variantas (fragmentas)

Fig. 6. Fragment of proposed version of integrated communication system in Vilnius metropolis

Straipsnyje minimuose šaltiniuose dažnai nurodoma svarbi aplinkybè: stengiamasi išlaikyti kompaktišką centrinį masyvą, o miesto ekspansija ị priemiestị spraudžiama į miesto $T w$ ar $M$ tęsinių koridorius. Panašaus tipo Berlyno plètra remiasi regioninio geležinkelio linijomis (vadinamoji decentralizuota koncentracija) ir dispersinès sklaidos miestų, miestelių vystymu stočių pasiekiamumo zonose (Strategy Report 1999).

Vienas iš Vilniaus miesto $2007 \mathrm{~m}$. bendrojo plano darbinių variantų buvo analogiškas plètros variantas, kurio idejja parodyta 6 pav. Tačiau ši idejja nebuvo vystoma. Priežastys ịvairios, svarbiausia - tai jau miesto regioninès plètros variantas, kuriam nagrinèti nebuvo institucinių, finansinių ir kitokių prielaidų.

\section{Tramvajaus idejos igyvendinimas}

Nors Vilniaus tramvajaus ideja gyva jau ne pirmą dešimtmetị, atrodo, kad ji baigia užgesti. Prie to prisideda ir bevaisè metropoliteno diskusinè alternatyva. Ilgainiui idejja devalvuosis, nors veiksmai siekiant ją igyvendinti jau turèjo būti toli pažengę.

Tramvajaus ar metropoliteno diskusijos ir Tw sprendinių egzistavimas miesto bendrajame plane turètų reikšti propagavimą - žinią, kad miestas vykdo atitinkamą viešojo transporto vystymo politiką. Teoriškai tikètini du igyvendinimo scenarijai:

Pirmasis scenarijus - daugiausia dèmesio skiriama pirmosios tramvajaus linijos tiesimui, tikintis, kad keleiviai atsiras savaime ir jų bus pakankamai. Tokiu atveju reiketų tikèti savaimine ir ilgai truksiančia $T w$ koridoriaus užstatymo transformacija, jeigu tai apskritai pasirodys patrauklu ir naudinga investuotojams, o transformacijos tikimybè pradès formuotis tik tuomet, kai prasides $T w$ tiesimo darbai. Tai pasyvus scenarijus, kurio sèkmè mažai tikètina, kaip ir apskritai keleivių grąžinimas ị viešojo transporto sistemą. Sąlygas diktuoja ir diktuos nevaržoma automobilizacija ir laisvai pasirenkamas gyventojų mobilumas.

Antrasis scenarijus - realiai suvokiamoje ateityje tramvajaus linijų tankis nebus didelis ir nepakartos viso dabar esančio troleibusų, o tuo labiau autobusų maršrutų tinklo. Todèl visos pastangos turètų būti skiriamos stabilizuoti ir permanentiškai didinti viešojo transporto svorị keleivių vežimų struktūroje ir kurti sąlygas, taip pat ir keleivių rinką bèginiam transportui. Per pastaruosius 20-30 ir daugiau metų Europos miestai išbandè daugybę urbanistinių, finansinių, administracinių ir inžinerinių priemonių bei būdų riboti lengvųjų automobilių naudojimą, o ribojimą kompensuoti kokybiškomis viešojo transporto paslaugomis.

Nei vienas iš Lietuvos miestų praktiškai nèra išbandęs panašių sisteminių priemonių. Miestams būdingas pasyvus laukimas, taip pat ir finansavimo šaltinių ir būdų. Geriausiu atveju vyrauja periferinio gatvių tinklo plètra, tiesiogiai nesprendžianti viešojo keleivių sistemos problemų ir palaikanti lengvụjų automobilių plètros potencialą.

Vis dažniau prisimenamas principas, kad taršos gamintojai, t. y. automobilių naudotojai, turètų sumokèti visą arba dalinę kainą už šalutinius produktus - triukšmą, taršą, eismo kamšą, eismo nelaimes ir kt. Pastaruoju metu ši principą garsiausiai priminė Londono ir Stokholmo miestai, îrengę mokamo įvažiavimo ị miestų centrus sistemas (tai proga priminti, kad mokamo ịvažiavimo ị Vilniaus senamiestị sistema veike 1994 m.). Jų veikla dar kartą patvirtino, kad mokestis gali reguliuoti automobilių srautą, iš dalies - perskirstyti keleivių rinką. Tačiau tai priklauso nuo mokesčio ir apmokestintos teritorijos dydžio. Ekonominis ir kitoks sistemų atsipirkimas priklauso nuo išorès kainų skaičiavimo metodikos, esamų VT pajègumų ir paslaugų kokybès bei jo transformacijos poreikio (apie tai plačiau (Juškevičius, Valeika 2007; Prud'homme, Kopp 2007). Tokio tipo apmokestinimo sistemos yra perspektyvios, nes jos jau dabar yra ateities transporto infrastruktūros finansavimo šaltinių prototipas.

Realiojo scenarijaus neįmanoma prognozuoti. Tramvajaus ir visos miesto transporto politikos „kor- 
tos" vertè gali svyruoti kas ketverius ar dažniau miesto politinès situacijos kaitos metus, tuo labiau, kad institucijos, turinčios žinių ir igaliojimus atsakingai vykdyti nuoseklią ir sisteminę miesto transporto politiką, nèra. Todèl yra didelè priklausomybè nuo paviršutiniško atsitiktinių ekspertų požiūrio.

\section{Išvados ir pasiūlymai}

Svarbiausioji išvada formuluotina kaip retorinis klausimas: kas prisiims atsakomybę už konstruktyvią diskusijų tema "tramvajus ar metropolitenas" pabaigą ir kas bei kada pradès $2007 \mathrm{~m}$. bendrojo plano sprendinio - tramvajaus sistemos pirmosios linijos tiesimo parengiamajj etapą. Nuo to priklausys tolesnè jo igyvendinimo eiga.

Kitos išvados:

- per artimiausius dešimtmečius metropolitenas objektyviai netaps alternatyva tramvajui;

- tramvajus ir regioninis, kartu ir miesto geležinkelis turi didelių vystymo perspektyvų integruotoje Vilniaus metropolio susisiekimo sistemoje.

Svarbiausias pasiūlymas ir argumentai:

a) Pirmosios tramvajaus linijos trasa iš pradžių turètų tapti eksperimentine viešojo transporto - troleibusų arba autobusų - nepertraukiamo prioriteto gatve su atitinkamais eismo organizavimo ir kitais pertvarkymais. Jeigu VT eismo intensyvumas būtų:

$<40$ transp. priem./h, gatvès ruožuose galètu veikti laikinos (kamšos valandomis ar kitu principu) specialios VT juostos, kuriomis galètų važiuoti taksi, maršrutiniai taksi ir pagalbos automobiliai;

$>40-60$ transp. priem./h, gatvès ruožuose turètų veikti nuolatinès specialios VT juostos. Centrineje miesto dalyje visa gatvès erdvé transformuojama ị viešąją erdvę, pritaikytą viešajam transportui, pėstiesiems ir dviratininkams.

b) Prioritetą viešajam transportui turètų garantuoti kompiuterine eismo valdymo ir informacinè kontrolès sistema.

c) Viešojo transporto prioriteto gatvè - tai veikiantis susisiekimo greičiu, reguliarumu ir kitomis imanomomis igyvendinti savybèmis imituojantis tramvajaus sistemą modelis. Jị naudojant galima išsiaiškinti beveik visus privalumus ir trūkumus, modifikacijų galimybes, patrauklumą. Tikètina, kad po 3-5 metu, aktyviai veikiant mobilumo valdymo principais, pradètu aiškèti
VT prioriteto gatvès sisteminè įtaka kitų viešojo transporto maršrutų tinklui, žemès naudojimo intensyvumo ir funkciniams pokyčiams.

d) Tokio modelio ilgalaikio naudojimo idèja iš esmès yra savivaldybès gebejimų identifikavimo vystymo tramvajaus sistemai igyvendinti rodiklis. Tai būtų labai svarbi žinia apie pasirinktą plètros strateginę kryptị - darniosios plètros principų ar kitokias koncepcijas ir galimas jų igyvendinimo pasekmes miesto raidai.

\section{Literatūra}

Accés transports viables. 20 septembre 2006. Communicué. Campagne Un tramway pour Quélec.

Albanese, J.; Gather, M.; Schneider, M. 2006. Light Transit Koncepte zur Moderniesierung des ÖRMVs: Das Beispiel der innerstödtischen Cross River Tram in greater London, Internationales Verkehrwesen 12: 595-601.

Andrusiewicz, A.; Grulikowski, S. 2001. Techniczne aspekty integraciji transportu szynowego w miastach, Transport miejski 3: 2-5.

Badcock, P. 2006. RandstadRail: Metro and Light rail make the connection, International Railway Journal 10: 32-35.

Brown, J. 2007. Londons future is by rail, Le Rail 136.

Burmeister, J. 2005. Renaissance der Strassenbahn in Frankreich, Verkehr und Technik 9: 348-354.

MAX Consortium (2007). Definition and Categorisation of Mobility Management Measures, in Internal report of project "Successful Travel Awareness Campaigns and mobility Management Strategies (MAX)" within Sixth Framework Programme (2002-2008). Prieiga per internetą: <http://www. max-success.eu>.

Dirvos ruošimas naujajam Almados tramvajui. 2004. Projekto STEP BY STEP - Save programos galutine ataskaita.

Hoogehuijs, H. 2005. Strassenbahnentwicklungen in der Niederlanden 2003-2005, Tadverkehr 5: 32-38.

Järviluoma, M. 2007. Helsinki region and public transport, Public Transport International 1: 8-10.

Juškevičius, P. 2002. Vilniaus miesto planavimo ir plètros raida, Urbanistika ir architektūra 26(4): 161-169.

Juškevičius, P. 2004. Miestu ir ju susisiekimo sistemu pletros harmonizavimas (teorijos ir praktika). Vilnius: Technika.

Juškevičius, P.; Valeika, V. 2007. Lietuvos miestu sistemu raida. Vilnius. Vilnius. 240 p.

Rat, H.; Pourbaix, J. 2007. Fostering the vitality of cities through good public transport, Railway gazette International. Metro Report: 8-10.

Maxman, R. J; Stuart, D. G. 1978. Sensitivity Analysis of Selected Transportation Control Strategies, Transp. Res. Rec. 677: $7-15$.

Mellas, G. 2007. Post-Olympic expansion offers beighter financial outlook, Railway gazette International. Metro Report: 21-22.

Other UK systems [interaktyvus] [žiūrèta $2003 \mathrm{~m}$. sausio 24 d.]. Prieiga per internetą: $<\mathrm{http} / / / \mathrm{www}$. nottinghamexpresstransit.com/network/other_trams.asp $>$. 
Prud'homme, R.; Kopp, P. 2007. Le péage du Stockholm: evaluation et enseigments, Transports 443: 175-189.

Stadtentwicklungsplan 1993. Entwurf. Arbeitskreis STEP. 275 p.

Strategy Report. 1999. Metropolitan Region Berlin Braundenburg. Gemeinsame Landesplanung Berlin Brandenburg. Potsdem. 96 p.

Tramway en Ile-de-France-où en est-on? [interaktyvus] [žiūrèta 2007 m. lapkričio 26 d.]. Prieiga per internetą: <http://www. linternaute.com/imprimer/paris/magazine/actualite/06/ transports/tramway/ >.

Transports urbains. Tramways en France [interaktyvus] [žiūrèta 2007 m. lapkričio 26 d.]. Prieiga per internetą: <http://www. quid.fr/2007/Transports_Urbains>.

Urban Track-Harmoniesierung stätischer Schienen-infrastruktur. 2007, Der Nahverkehr 3: 8-12.

Wansbeek, C. 2007. Bucharest. New trams, line refurbishement, Tramways \& Urban Transit 836: 301-304.

Васильев, Г. 2007. Новая жизнь трамвая, Транспорт России 10: 4 .

\section{TRAM / METRO IN URBAN STRUCTURE OF VILNIUS. PROPOSALS AND ARGUMENTS}

\section{P. Juškevičius, V. Valeika, K. Jauneikaitè}

Abstract. Until now and continuously in future communication problems in Vilnius will be caused by residents' mobility and chosen communication means as well as the way of living in urban structure, street network and other type of environment. Regulation (management) of such an entirety would be a clue for solving the problems. In nowadays discussions there are no mentions about such an entirety or tram/metro functional environment. Efforts to find proper development proportions of public and personal transportation systems are one of measures for real problem solution. With this purpose social and political communication system environment, flow de facto and transportation potency, mobility management and importance of urban structure were approached in this work in general and specifically for Vilnius case. Suggestions and arguments for tram system implementation are given in the paper.

Keywords: urban communication system, tram, metro, mobility, urban structure.

\section{PRANCIŠKUS JUŠKEVIČIUS}

Dr Habil, Prof, Dept of Urban Design, Vilnius Gediminas

Technical University (VGTU), Pylimo g. 26/Traku g. 1, LT-01132

Vilnius, Lithuania.E-mail: sj@amstudio.lt

Publications: author of over 70 research papers, 5 monographs. Projects: project leader of various land use (rural territories) plans, transport feasibility studies. Research interests: urbanism, land use planning for rural territories, planning public transport system.

\section{VIDUALDAS VALEIKA}

Senior specialist, ME "Vilniaus planas", Konstitucijos pr. 3, LT09601 Vilnius, Lithuania. E-mail: vidualdas.valeika@vilnius.lt

Publications: author of over 10 research papers, 2 monographs. Projects: author of different kinds of transportation plans (like part of land use document, feasibility study, etc.). Research interests: planning urban and rural communication systems.

\section{KRISTINA JAUNEIKAITE்}

Doctoral student, assistant, Dept of Urban Engineering, Vilnius Gediminas Technical University (VGTU), Sauletekio al. 11, LT-10223 Vilnius, Lithuania.E-mail: kris@ap.vgtu.lt

Publications: author or co-author of 5 research papers. Projects: project leader or co-author of various land use planning projects. Research interests: mobility management, integration of mobility planning. 